\title{
Natural Plants with Anticancer Activity
}

\author{
Sukhraj Singh *, Mandeep Singh \\ Sri Sai College of Pharmacy, Manawala, Amritsar-143115, Punjab, India
}

Address for Correspondence: Sukhraj Singh

\begin{tabular}{l} 
Received: \\
01.03.2019 \\
Accepted: \\
25.03.2019 \\
Keywords \\
Medicinal Plants; \\
Herbal \\
Medicines; \\
Anticancer \\
Drugs. \\
\hline
\end{tabular}

\section{Received:}

Accepted:

\section{Keywords}

Medicinal Plants;

Herbal

Drugs.
ABSTRACT: Cancer is the instant leading cause of death world-wide. In 2018, predictable 1,735,350 new cases of cancer will be diagnosed in the United States and 609,640 people will die from the disease. There is a well-known demand for new therapies to treat and prevent this life-threatening disease. It is transmitted from generation to generation within cultures. Natural drugs to have less toxic side effects compared to modern treatments such as chemotherapy. The use of the podophyllotoxin plants in cancer avoidance and management. Many previous studies showed that a wide range of medicinal plants exert cytotoxic and anticancer action. PTOX has anti-neoplastic properties that prevent the assembly of tubulin into microtubules and persuading apoptosis. Podofilox is a lignan (LIGNANS) found in PODOPHYLLIN resin from the roots of PODOPHYLLUM plants. It shows strong cytotoxic activity against a variety of cancer cell lines by inhibiting microtubule assembly. (C) 2019 iGlobal Research and Publishing Foundation. All rights reserved.

Cite this article as: Singh, S.; Singh, M. Natural Plants with Anticancer Activity. Indo Global J. Pharm. Sci., 2019; 9(2Suppl.): 139. DOI: http://doi.org/10.35652/IGJPS.2019.92S37.

Indo Global Journal of Pharmaceutical Sciences( ISSN 2249 1023; CODEN- IGJPAI; NLM ID: 101610675) indexed and abstracted in CrossRef (DOI Enabling), UGC CARE Journal List, EMBASE(Elsevier), National Library of Medicine (NLM) Catalog, ResearchGate, Publons, CAS (ACS), Index Copernicus, Google Scholar and many more. For further details, visit http://iglobaljournal.com

This is a special issue as an outcome of 'RAPSCON-2019' sponsored by APTI and organized by Sri Sai College of Pharmacy, Manawala, Amritsar, Punjab, India. Relaxation offered in journal format. 